\title{
Quantification of CAMP and CGMP analogs in intact cells: pitfals in enzyme immunoassays for cyclic nucleotides
}

Katharina Werner ${ }^{1 *}$, Frank Schwede ${ }^{2}$, Hans-Gottfried Genieser ${ }^{2}$, Jörg Geiger ${ }^{1}$, Elke Butt ${ }^{1 *}$

From 5th International Conference on cGMP: Generators, Effectors and Therapeutic Implications

Halle, Germany. 24-26 June 2011

\section{Background}

The present work evaluates the cross-reactivity of commercially available cyclic nucleotide analogs with cAMPand cGMP-immunoassays from Cayman, IBL (both IBL International, Hamburg, Germany) and ENZO Life Sciences (Loerrach, Germany).

\section{Results and conclusion}

Most of the tested cyclic nucleotide analogs showed low degree competition with the antibodies; however, with Rp-cAMPS, 8-Br-cGMP and 8-pCPT-cGMP a strong cross-reactivity with the ENZO cAMP- respectively cGMP-EIA and the IBL cGMP-RIA was observed (Table

Table 1 Lipophilicity $\left(\log K_{w}\right)$, cell permeability and EIA/RIA specificity of selected cyclic Nucleotide analogs.

\begin{tabular}{|c|c|c|c|c|c|c|}
\hline Analog & $\begin{array}{r}\log \\
\mathrm{K}_{\mathrm{w}}\end{array}$ & Permeability & $\begin{array}{c}\text { Specificity ENZO } \\
\text { CAMP-EIA }\end{array}$ & $\begin{array}{c}\text { Specificity ENZO } \\
\text { CAMP-EIA }\end{array}$ & $\begin{array}{c}\text { Specificity IBL } \\
\text { CGMP-RIA }\end{array}$ & $\begin{array}{c}\text { Specificity Cayman } \\
\text { CGMP-EIA }\end{array}$ \\
\hline 2'-dcGMP & 0.65 & $0 \%$ & & $5.21 \%$ & & \\
\hline cGMP & 0.77 & & & $100 \%$ & $100 \%$ & $100 \%$ \\
\hline Rp-cGMPS & 0.89 & & & $0.27 \%$ & $10.6 \%$ & \\
\hline 2'-dcAMP & & $0 \%$ & $2.4 \%$ & & & \\
\hline CAMP & 1.09 & & $100 \%$ & & & \\
\hline 8-Br-cGMP & 1.17 & $12.1 \%$ & & $490 \%$ & $20 \%$ & $0.5 \%$ \\
\hline Rp-cAMPS & 1.21 & $12.2 \%$ & $68 \%$ & & & \\
\hline 8-Br-cAMP & 1.35 & $8.0 \%$ & $0.4 \%$ & & & \\
\hline Rp-8-Br-cAMPS & 1.47 & & $0.3 \%$ & & & \\
\hline 6-MB-cAMP & 1.64 & & $0.4 \%$ & & & \\
\hline 6-Bnz-cAMP & 1.9 & & $0.6 \%$ & & & \\
\hline 8-pCPT-cGMP & 2.52 & $19.6 \%$ & & $240 \%$ & $30 \%$ & $0.008 \%$ \\
\hline 8-pCPT-cAMP & 2.65 & $22.0 \%$ & $0.05 \%$ & & & \\
\hline 8-Br-PET-cGMP & 2.83 & $30.9 \%$ & & $10 \%$ & $0.15 \%$ & $1.6 \%$ \\
\hline Rp-8-Br-PET-cGMPS & 2.83 & & & $0.2 \%$ & & \\
\hline $\begin{array}{c}\text { 8-pCPT-2'-OMe-cAMP (Epac } \\
\text { Activator) }\end{array}$ & 2.94 & & $0.03 \%$ & $0.02 \%$ & & \\
\hline Sp-5,6-DCl-cBIMPS & 2.99 & & $<0.001 \%$ & & & \\
\hline
\end{tabular}

\footnotetext{
* Correspondence: butt@klin-biochem.uni-wuerzburg.de

${ }^{1}$ Institute for Clinical Biochemistry and Pathobiochemistry, University of

Wuerzburg, Germany

Full list of author information is available at the end of the article
} 
1). As a consequence we tested these derivatives with the Cayman cGMP-EIA. This assay is less sensitive to cGMP $(1.0 \mathrm{pmol} / \mathrm{ml})$ than the ENZO cGMP-EIA $(0.01$ $\mathrm{pmol} / \mathrm{ml}$ ), however the specificity concerning cGMPanalogs is superior and therefore advantageous when measuring cGMP in the presence of 8-Br-cGMP or 8pCPT-cGMP.

The determined EIA binding constants enabled the measurement of the intracellular cyclic nucleotide concentrations and revealed a time- and lipophilicity-dependent cell membrane permeability of the compounds in the range of $10-30 \%$ of the extracellular applied concentration after $20 \mathrm{~min}$ (Table 1).

\section{Author details}

'Institute for Clinical Biochemistry and Pathobiochemistry, University of

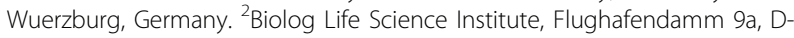
28199 Bremen, Germany.

Published: 1 August 2011

doi:10.1186/1471-2210-11-S1-P75

Cite this article as: Werner et al:: Quantification of CAMP and CGMP analogs in intact cells: pitfals in enzyme immunoassays for cyclic nucleotides. BMC Pharmacology 2011 11(Suppl 1):P75.
Submit your next manuscript to BioMed Central and take full advantage of:

- Convenient online submission

- Thorough peer review

- No space constraints or color figure charges

- Immediate publication on acceptance

- Inclusion in PubMed, CAS, Scopus and Google Scholar

- Research which is freely available for redistribution

Submit your manuscript at www.biomedcentral.com/submit
C Biomed Central 